\title{
Political Reporting: Its Regulatory Framework and Imperatives on Democracy and Democratisation of Communication in Nigeria
}

\author{
By Charles Obot*
}

Political reporting offers the citizenry the opportunity to be informed of current issues in the political sphere. It provides the link between the politician/government and the electorate. Much of what the citizenry knows about government activity or the politician is made possible by political reporting. Since democracy finds its essence in the electorate making informed choices, political reporting therefore becomes indispensable in modern democracies. Since political reporting cannot be done in a vacuum, certain principles have to be adhered to/ taken into consideration. These include: the political environment, regulatory framework, equal opportunity, fairness and democratisation of communication. Moreover, the political reporter is expected to demonstrate a high level of social responsibility and professionalism.

Keywords: Political Reporting; Regulatory Framework; Democracy and Democratisation of Communication

\section{Introduction}

Political reporting offers the citizenry the opportunity to be informed of current issues in the political sphere. It provides the link between the politician/ government and the electorate. Much of what the citizenry knows about government activity or the politician is made possible by political reporting. Since democracy finds its essence in the electorate making informed choices, political reporting therefore becomes indispensable in modern democracies.

This paper would be discussed under the following sub-headings:

i. Keywords: Political reporting and government broadcast media.

ii. Theoretical framework: Democratic-participant media theory.

iii. Politics: The origin of government's interest in the broadcast media in Nigeria.

iv. Regulatory framework of political reporting and advertisements in Nigeria.

$\mathrm{v}$. The imperatives of political reporting in the government broadcast media.

*PhD Associate Professor, Department of Communication Arts, University of Uyo, Nigeria. Emails: charlesdenis@uniuyo.edu.ng and charlesobot2000@yahoo.com 


\section{Theoretical Framework}

The Democratic-participant media theory serves as the theoretical framework of this paper. According to McQuail ${ }^{1}$, "the central point of a democratic participant theory lies with the needs, interests and aspirations of the active 'receiver' in a political society. It has to do with the right to relevant information, the right to answer back, the right to use the means of communication for interaction in small-scale settings of community, interest group, sub-culture". According to him, the principles of the theory are summarised as follows:

- Individual citizens and minority groups have rights of access to media (rights to communicate) and rights to be served by media according to their own determination of needs.

- The organisation and content of media should not be subject to centralised political or State bureaucratic control.

- Media should exist primarily for their audiences and not for media organisations, professionals or the clients of media.

- Groups, organisations and local communities should have their own media.

- Small scale, interactive and participative media forms are better than large-scale, one-way, professionalised media.

- Certain social needs relating to mass media are not adequately expressed through individual consumer demands, nor through the State and its major institutions.

- Communication is too important to be left to professionals.

\section{Politics: The Origin of Government's Interest in the Broadcast Media in Nigeria}

Government interest in the mass media dates back to the pre-independence era. Lasode traces the emergence of television broadcasting in Nigeria to an incident in the House of Representatives in $1953 .^{2}$ Eager for independence; Chief Anthony Enahoro - an Action Group member of the House moved the motion for self-government for Nigeria. The motion was opposed by members from the Northern Peoples Congress who constituted half the membership. Angered by this, the Action Group members led by Chief Obafemi Awolowo declared the Macpherson Constitution inoperative and walked out of the Assembly. The Action Group Ministers immediately resigned from the Federal Cabinet and this led to a Constitutional crisis. Disappointed by the decision of the Action Group Ministers, the Chief Secretary to the Nigerian Government Mr. A. E. T. Benson telephoned Governor Macpherson urging him to make a

\footnotetext{
${ }^{1}$ McQuail (1987) at 120-121.

${ }^{2}$ Lasode (1994) at 17.
} 
broadcast on Nigerian Broadcasting Service (NBS) to the country about what was termed "perfidy of the Action Group". The Governor reluctantly made the broadcast. The following morning, Chief Awolowo telephoned the Director of NBS requesting equal time. Director Chalmer was quite ready to let Chief Awolowo refute what he claimed was a misrepresentation of the Action Group's point of view. However, the Secretary to Nigerian Government, Mr. Benson prevented Chief Awolowo from making his broadcast. Chief Awolowo was furious and accused NBS of being a tool manipulated by the government. This and other disenchantment with the inability of NBS to accomplish diversity in dealing with Regional interests led to the establishment of Western Nigerian Television in 1959 by Chief Obafemi Awolowo, followed by a radio service - Western Nigerian Broadcasting Service (WNBS) in May 1960. The Eastern Region established the ENTV on October 1, 1960, while the Northern Region established a radio and television service - the Radio Kaduna Television (RKTV) in 1962.

There was a general belief in the need for a Federal Broadcasting Corporation, independent of government that would serve the needs of everyone in the country no matter his or her political or tribal persuasion. The Nigerian Broadcasting Service was severely attacked by the Nigerian Press and the public for being a government tool. The nation wanted the NBS to be impartial and to reflect divergent views and the cultural set up of the nation. On April 1, 1957 the Nigerian Broadcasting Service (NBS) by an Act of Parliament was converted into a statutory corporation to be thenceforth known as Nigerian Broadcasting Corporation (NBC). The reason was to shield it from government interference and propagation of the views of the ruling political party. The NBC was then created to allay public fears of government monopoly of broadcasting. It became public property.

As recalled by Mackay ${ }^{3}$, the Federal Government's admiration for a completely independent broadcasting corporation was short-lived, for in August 1961, the Federal Minister of Information - Honourable T. O. S. Benson sought leave to:

\section{[...] amend the Nigerian Broadcasting ordinance to enable the Minister responsible for broadcasting to give general and specific directives to the corporation on matters appearing to the Minister to be of public interest and also enable him, after consultation with the appropriate Regional Government in the case of regional boards, to make recommendations to the Governor-General in Council as to the appointment of all members of the Corporation.}

The original ordinance carefully avoided giving the Federal Government or the Minister any powers to give directives to the corporation. The Corporation was also given the right to say that a particular item was inserted in its programme at the request of the government. But under the 1961

\footnotetext{
${ }^{3}$ Mackay (1964) at 66.
} 
Amendment Act, the government or Minister of Information had the right to give specific or general directives to the corporation. This attracted some criticism.

Mackay ${ }^{4}$ noted that 'Aiyekoto' - a pseudonym used by Bisi Onabanjo headed his attack of the amendment in the Daily Express with these words: "Now Radio Nigeria becomes Radio Benson". Mackay ${ }^{5}$ also reports that John West - a pseudonym adopted by the eminent journalist - Lateef Jakande headed his criticism in The Service thus: "Mr. Benson Takes a Wife" and expressed fears that NBC would cease "to be either impartial or objective, or independent". John West suggested that the Minister should "find out how many listeners his Corporation has lost to WNBS". John West also remarked that the Federal Minister of Information "can compel the NBC to broadcast propaganda. He cannot compel the public to listen to it $[\ldots]$ ".

Nwuneli also quotes 'Aiyekoto' thus:

[...] every Nigerian tunes to the NBC when it is time for news, because he believes he is going to get unbiased news. In fact, I do not mind telling my $N B C$ friends that the only useful programme they have is their news programme. It has a prestige now because it is believed that it is outside government control. Now that it is going under this control, the NBC may as well fold up. ${ }^{6}$

From the above comments, it is apparent that before the amendment, the NBC news programme was considered credible and it enjoyed massive listenership.

This is the idea behind public service broadcasting. The 2000 Report of the World Radio and Television Council, Public Broadcasting: Why? How? describes the principles of independent public service broadcasting as being universality, diversity, independence and distinctiveness, and explains them as follows:

- It is accessible to every citizen, not merely in technological terms, but also in terms of the intelligibility of the programming.

- It demonstrates diversity in the genres of programmes offered, the audiences targeted and the subjects discussed.

- It is independent of commercial pressures and political influence. This includes editorial independence, protections for freedom of expression, adequate, predictable and independent mechanisms of financial autonomy and the independence of governing bodies and the disolution process for their boards and chief executives.

- It not only produces types of programmes and subject matter other services ignore and targets audiences others neglect but, without excluding any genre, it aims to innovate, create new genres, and set the pace in the audiovisual world.

\footnotetext{
${ }^{4}$ Mackay (1964) at 69.

${ }^{5}$ Mackay (1964) at 70.

${ }^{6}$ Nwuneli (1985) at 209.
} 
The mandate of the public service broadcaster may include a range of duties and responsibilities designed to serve the public service, such as:

- Provide comprehensive, balanced and impartial news and current affairs programmes, including national and international affairs of general public interest.

- Provide programming of wide appeal as well as specialised programming.

- Contribute to national identity while also reflecting cultural and regional diversity.

- Give a voice to minority groups, including minority languages.

- Provide a reasonable proportion of educational programmes.

- Provide a reasonable proportion of programmes for children, and

- Promote programme-making by in-country producers, including regional production.

\section{Regulatory Framework of Political Reporting in Nigeria}

There are some regulatory provisions governing political reporting and advertisements in the Nigerian mass media. These include the Nigeria Broadcasting Code (NBC), Electoral Act 2010 and the Advertising Practitioners Council of Nigeria (APCON) Code. Relevant sections of these Codes are presented below:

\section{Political Objectives of Broadcasting in Nigeria (NBC Code 0.3.2.4)}

To contribute to the development of national unity and participatory democracy. Therefore, broadcasting shall:

a. create and promote political awareness amongst the people in order to achieve a democratic society;

b. inculcate in the people the spirit of tolerance of all shades of opinion;

c. promote social justice based on the responsibilities and rights of the individuals in society.

- News material shall not be recreated.

- News, commentaries, analyses and editorials shall be clearly identified as such.

- Commercials in News and Current Affairs programmes shall be clearly identified and presented in a manner that shall make them clearly distinguishable.

- The promotion of an organisation, product or a service of commercial interest shall not be treated as news analysis, commentary or editorial.

- The use of terminologies such as "analysts", "observers", etc., shall not be accepted as attribution in a news report. 
- Pane lists shall be of comparable status and relevance.

\section{Political Broadcasts (NBC Code 5.2)}

- Political programmes shall observe the provisions of the Code, and other extant laws relating to broadcasting.

- All political broadcasts shall be the product of the broadcaster except advertisements, promos and collaborative productions supervised by relevant organisations like BON, INEC, NOA, etc.

- All broadcasters shall carry out their civic responsibility of transmitting all aspects of political enlightenment.

- Partisan political broadcasts shall be only those in which the Parties seek to explain their views and policies.

- Political broadcasts shall be in decent language.

- Political broadcast broadcasts shall be clearly identified as such, and shall not be presented in a manner that would mislead the audience to believe that the programmes are of any other character.

- A broadcaster shall, in using political material for news, avoid taking inflammatory and divisive matter in its provocative form.

- In adherence to the principles of pluralism, equal airtime shall be provided to all political parties or views, with particular regard to the amount of time and belt, during political campaign period.

- All broadcasters shall regularly broadcast announcements to the effect that every political party is entitled to air time during political campaign periods.

- At campaign periods, log books shall be kept by each broadcaster at a level not below the level of a "Controller" or its equivalent, showing the allocation of news, programmes and commercial air-time to each Party with dates, title and other information as may be requested by the Commission to ensure fairness.

- All partisan political broadcasts shall be recorded at transmission point and preserved for at least 90 days after first broadcast.

- All partisan political broadcasts, campaigns, jingles, announcements and the use of all forms of partisan political party identifications or symbols on air shall end not later than twenty-four hours before polling day.

- In exceptional circumstances, an office holder may, within the 24 hour period, perform a service relating to his office, provided there is no display of partnership.

- A broadcaster shall not use any vote obtained at different polling stations or from exit polls, or project or speculate on the chances of the candidates. 
- A broadcaster shall broadcast electronic results or declaration of the winner only as announced by the authorised electoral officer for the election.

- In the interest of fairness and balance, any form of commercialisation of political news is not allowed.

- No political jingle shall exceed 60 seconds.

- While a broadcast producer may interact with politicians in the course of his professional duties, this shall not be such, as to lead to the belief, that he is either a member or sympathiser of any political party.

- A broadcaster shall avoid adulation and the tendency to glamorise persons or resort to praise singing or denial of access to those of contrary views or political leanings to such persons.

- In programmes requiring the representation of political parties or affiliations, the pane lists shall be of comparable status and relevance.

- No pane list shall use Party logo, insignia, etc. to the disadvantage of other pane lists.

- A broadcaster shall set up a standing Electoral Complaints Committee to resolve all disputes within 24 hours of receipt of the complaint.

- The appropriate decisions, including the grant of a Right of Reply or Apology, shall be implemented within 24 hours, and at the same level of prominence.

- The Committee's proceedings shall be forwarded to the Commission not later than 48 hours.

\section{Political Advertising (NBC Code 7.6)}

- A political advertisement shall be guided by the extant laws(s), the Code and other relevant regulations.

- A broadcaster shall be free to sell airtime for the purpose of political campaigns provided that:

- All messages shall be in the form of spot announcements or jingles not exceeding 60 seconds;

- No broadcaster shall be involved in the production of such announcements or jingles;

- No voice of any on-air staff of any broadcast station shall be used in political jingles;

- All jingles shall conform to the standards of truth, decency, good taste and morality.

- No advertisement shall be accepted in a partisan political programme.

- The advertiser shall be clearly identified in all advertisements.

- No broadcaster shall deny any person, party or group a right of broadcast of a political advertisement. 
- The period of campaign through any broadcast media in any election by every political party shall commence 90 days before polling day and end 24 hours prior to that day.

- No broadcaster shall permit any political campaign or advertisement on its facilities 24 hours immediately preceding polling day or on polling day.

- All broadcasters shall give equal access to all registered political parties or candidates on their facilities.

- Airtime shall be allocated equally among the political parties at similar hours of the day.

- All broadcast stations shall allot equal airtime to all political parties during prime times and at similar hours each day, subject to the payment of appropriate fees.

- All broadcasting stations shall ensure equal coverage to all political parties.

- No broadcasting station shall be employed or used to the advantage or disadvantage of any political party or candidate at any election.

- It shall be the duty of the broadcaster to authenticate purported withdrawal of a candidate in an election and ensure that the affected candidate personally endorses such claim.

- Any broadcast station that contravenes the provisions of Sections 7.6.6 to 7.6.13 above, shall be liable, in the first instance to a fine of $\mathrm{N} 500,000$ and $\mathrm{N} 1,000,000$ for subsequent breach(es) suspension or revocation of licence.

\section{Electoral Act, 2010, Section 95, Sub-sections 1 - 3, Section 100, Sub-sections 1 -6 , Section 102}

1. A political campaign or slogan shall not be tainted with abusive language directly or indirectly likely to injure religious, ethnic, tribal or sectional feelings.

2. Abusive, intemperate, slanderous or base language or insinuations or innuendoes designed or likely to provoke violent reaction or emotions shall not be employed or used in political campaigns.

3. Places designated for religious worship, police station and public offices shall not be used:

a. for political campaigns, rallies and processions; or

b. to promote, propagate or attack political parties, candidates, their programmes or ideologies.

4. A candidate and his Party shall campaign for the elections in accordance with such rules and regulations as may be determined by the Commission.

5. State apparatus including the media shall not be employed to the advantage or disadvantage of any political party or candidate at any election. 
6. Media time shall be allocated equally among the political parties or candidates at similar hours of the day.

7. At any public electronic media, equal airtime shall be allotted to all political parties or candidates during prime times at similar hours each day, subject to the payment of appropriate fees.

8. At any public print media, equal coverage and conspicuity shall be allotted to all political parties.

9. A public media that contravenes subsections (3) and (4) of this section commits an offence and is liable on conviction to a maximum fine of $\mathrm{N} 500,000.000$ in the first instance and to a maximum fine of $\mathrm{N} 1,000,000$ for subsequent conviction.

a. A person, print or electronic medium that broadcasts, publishes, advertises or circulates any material for the purpose of promoting or opposing a particular political party or the election of a particular candidate over the radio, television, newspaper, magazine, handbill, or any print or electronic media whatsoever called during 24 hours immediately preceding or on polling day commits an offence under this Act,

b. A candidate, person or association who engages in campaigning or broadcasting based on religious, tribal or sectional reason for the purpose of promoting or opposing a particular political party or the election of a particular candidate, commits an offence under this Act and is liable on conviction to a maximum fine of $\mathrm{N} 1,000,000$ or imprisonment for a term of 12 months or to both.

\section{APCON Code on Political Advertising}

The Code of advertising practice of the Advertising Practitioners Council of Nigeria (APCON) makes the following provisions for political advertising in Nigeria.

i. Truth: Political ads shall not be deceptive or misleading in word, photography, film or sound.

ii. False Claims: Political advertisements shall be issue-oriented and devoid of abusive statements or references.

Furthermore, they should not employ fake, distorted or unsubstantiated claims or misrepresentations.

iii.Advertiser's Identity: Every political advertisement must clearly identify the sponsoring organisation or individual, visually and orally. Anonymous sponsors like "Committee of friends" must be avoided.

iv. Sectional interest: Political advertisement shall not explicitly or implicitly exploit ethnicity, religion or any other sectional interest not strictly related to political issues under discussion. 
v. Agency conduct: Agencies engaged in political advertising must not produce or use any material that is capable of bringing the advertising profession into disrepute.

vi. Equal opportunity: Political candidates must be given equal opportunity to buy space and/or air time. "Equal opportunity" means that each competing candidate must have equal access to comparable space and/or air time, generally on the basis of first come, first served.

vii. Compliance: Media houses, agencies, political parties, politicians and their agents must ensure that political advertisements are in consonance with the provisions of the Code. When in doubt, they should seek immediate clarification from APCON Secretariat.

Adherence to the APCON Code in political advertising in Nigeria is difficult to ascertain as information on enforcement by APCON is not widely publicised.

\section{The Imperatives of Political Reporting: Equal Opportunity, Fairness, Democracy, Democratisation of Communication and Social Responsibility}

Political reporting is the art of gathering, writing or presenting stories about politics, political activities or issues that border on government and governance. Government broadcast media are electronic organisation that depend on direct funding from and under direct control of the government of the day.

Political reporting in a government broadcast medium is a very challenging endeavour, and it often sets the political reporter on a collusion course with the government or political party in power. Whether in a government broadcast media, truly publicly owned or privately owned the imperatives of political reporting are similar.

Islam notes that:

the media industry, whether public or private, plays an important role in any economy by garnering support or opposition for those who govern, by highlighting or failing to do so the views and/or sins of industry, by providing a voice for the people or not doing so, and by simply spreading economic information. ${ }^{7}$

The mass media not only carry information about the economy, but also messages about the social, political and religious lives of the people. In the opinion of Wolfensohn,

a free press is not a luxury. It is at the core of equitable development. The media can expose corruption. They can keep a check on public policy by throwing a spotlight on government action. They let people voice diverse

${ }^{7}$ Islam (2002) at 3. 
opinions on governance and reform, help build public consensus to bring about change. ${ }^{8}$

It can be deduced from Wofensohn's opinion that easy and equitable access to the mass media as well as diversity of views in media contents are not only indispensable, but are also crucial for the emergence of a democratic society and attainment of development. Unfortunately, many people have observed on many occasions that the mass media in Nigeria have not been the "market place of ideas" they are supposed to be. The principle of equal opportunity is central to coverage of electoral campaigns in a multi-party democracy.

According to Dominick ${ }^{9}$, equal opportunity rule stipulates that if a station permits one candidate for a specific office to appear on the air, it must offer the same opportunity to all other candidates for that office. If a station gives a free minute to one candidate, all other legally qualified candidates for that office are also entitled to free a minute. Same goes for the cost of air time.

Wilson recalls that the United States Congress included the 'equal opportunity provision in the 1927 Federal Radio Commission (FRC) and 1934 Federal Communication Commission (FCC) Acts to protect candidates for political office. $^{10}$

Nwodu defines electoral campaign as:

the overall deliberate, planned well-articulated and sustained messageoriented effort aimed at presenting a candidate for political office to the electorate with a view to attracting voters' sympathy and consequently, moving the electorate to vote massively for the candidate so presented. ${ }^{11}$

Democracy thrives on the principles of informed electorate making responsible choices and decisions. The mass media are not only key avenues for providing the required information; they also determine what is available in the public domain. This is a result of what Gurevitch and Blumber call three sources of media power. These are structural, psychological and normative. According them, the structural root of the power of the mass media "springs from their unique capacity to deliver to the politician an audience, which in size and composition, is unavailable to him by any other means". ${ }^{2}$

The psychological root of the media power stems from the relationships of credibility and trust that different media organisations have succeeded in developing (albeit to different degrees) with members of their audiences. Gurevitch and Blumber assert that:

\footnotetext{
${ }^{8}$ Wolfensohn (2002) at v.

${ }^{9}$ Dominick (1990) at 441.

${ }^{10}$ Wilson (1993) at 78.

${ }^{11}$ Nwodu (2003) at 53.

${ }^{12}$ Gurevitch \& Blumler (1977) at 274.
} 
it is the combined influence of this structural and psychological source of strength that enable the media to interpose themselves between politicians and the audience and to 'intervene' in other political processes as well. ${ }^{13}$

This interposition, according to them, is expressed in the way in which the mass media are capable of restructuring the timing and character of political events (conventions, demonstrations, leader appearances, etc.), defining crisis situations to which politicians are obliged to react, requiring comment on issues that media personnel have emphasised as important, injecting new personalities into the political dialogue (such as television interviews) and stimulating the growth of new communication agencies (such as public relations firms, opinion poll agencies, and political advertising and campaign management specialists). On the other hand, the normative root of media power stems from the respect that is accorded in competitive democracies to such tenets of liberal philosophy as freedom of expression and the need for specialised organs to safeguard citizens against possible abuses of political authority.

Pate emphasises that political reporting is necessary for sustenance of democracy where the system of checks and balance is required for good governance. ${ }^{14}$ In doing do, Wilson advises that such activity should be "ruled by fairness or equal opportunity, right of access and reply so that contending contrary positions can be heard." 15 To ensure equal opportunity in the coverage of electoral campaigns by public media in the country, the Electoral Act 2010, Section 100 makes the following provisions.

(i) A candidate and his party shall campaign for the election in accordance with such rules and regulations as may be determined by the commission.

(ii) State apparatus including the media shall not be employed to the advantage or disadvantage of any political party or candidate at any election.

(iii) Media time shall be allocated equally among the political parties at similar hours of the day.

(iv) At any public electronic media, equal coverage and conspicuity shall be allotted to all political parties.

(v) At any public print media, equal coverage and conspicuity shall be allotted to all political parties.

(vi) Any public media that contravenes sub-sections (3) and (4) of this section shall be guilty of an offence and on conviction be liable to a fine of $\$ 500,000$ in the first instance and to a fine of $\$ 1,000,000$ for subsequent conviction.

\footnotetext{
${ }^{13}$ Gurevitch \& Blumler (1977) at 75.

${ }^{14}$ Pate (2003) at 129.

${ }^{15}$ Wilson (2003) at 121.
} 
Emphasising the desirability of equal opportunity in electoral campaigns coverage, Sotunmbi suggests that Party functionaries should be invited to talk to the audience on the Party manifesto according to an agreed time-table. The duration of time allocated to each Party should be the same and care must be taken to ensure that the broadcasts are scheduled such that no political party is seen to have gained an undue advantage over the other. ${ }^{16}$

Chester, Garrison and Willis ${ }^{17}$ recall the provision of Section 315 of FCC Act in part:

if any license shall permit any person who is a legally qualified candidate for any public office to use a broadcasting station, he shall afford equal opportunities to all other such candidates for that office in the use of such broadcasting station, and the Commission shall make rules and regulations to carry this provision into effect: provided, that such licensee shall have no power of censorship over the material broadcast under the provisions of this section. No obligation is hereby imposed upon any licensee to allow the use of its station by any such candidate.

This provision means that television and radio stations must offer free time or sell time on equal basis (including identical discounts) to all legally qualified candidates for the same office during a political primary or election campaign. Congress made some exceptions to this law. Wilson explains the exceptions thus: appearance by a legally qualified candidate on any (a) bona-fide newscast (b) Bona-fide news interview (c) Bona-fide news documentary (if the appearance is incidental to the presentation of the subject or subjects covered by the news documentary), or (d) on-the-spot coverage of bona-fide news events (including, but not limited to political conventions and activities incidental thereto), shall not be deemed to be use of a broadcasting station within the meaning of this sub-section. ${ }^{18}$

Nothing in the foregoing sentence shall be construed as relieving broadcasters, in connection with the presentation of newscast, news interview, news documentaries and on-the - spot coverage of news events, from the obligation imposed upon them under this Act to operate in the public interest and to afford reasonable opportunity for the discussion of conflicting views on issues of public importance. The point that the public is entitled to hear a reasonable balanced presentation of all responsible viewpoints on particular issues came to be known as the Fairness Doctrine.

FCC made it clear that the doctrine did not require that equal time be provided for every view, nor was it necessary to permit a spokesman for every side to be heard. The station met the requirement of the doctrine if in its overall programming it provided a reasonable exposure to the various points of view on a controversial issue. However, the FCC did lay down some specific rules with respect to certain types of programmes. If honesty, integrity or character

\footnotetext{
${ }^{16}$ Sotunmbi (1999) at 216.

${ }^{17}$ Chester, Garrison and Willis (1971) at 137-138.

${ }^{18}$ Wilson (1993) at 78.
} 
of a group or person were attacked in connection with the discussion of a controversial issue, the FCC required that the subject of the attack be notified of the date and time of the broadcast, be sent a tape, script or summary of the attack within seven days, and be afforded a reasonable opportunity to rely. If a station endorses political candidates, it was required to notify opponents within 24 hours and provide an opportunity for replies by other candidates or their spokesman. If the endorsement took place within 72 hours of the election, other candidates had to be notified prior to the broadcast.

Although the fairness doctrine was abolished in America in $1987^{19}$, two corollaries to the Fairness Doctrine remain in effect: these are the personal attack and the political editorial rules. The personal attack rule requires that broadcast licensees provide time for individuals to respond to personal attacks made during discussions of controversial public issues. Broadcasters must provide political candidates the opportunity to respond to editorials attacking them or supporting their opponents. Stations must notify the person attacked, or the candidate, provide them with a script or tape of the programme where the attack or endorsement was made, and allow for a reasonable opportunity to respond without financial charge.

When the original Fairness Doctrine Rule was in force, broadcasters were required to seek out and present contrasting viewpoints on controversial matters of public importance. On any issue, broadcasters had to make a good faith effort to cover all the opposing viewpoints. This did not have to take place in one programme, but the broadcaster was expected to achieve the balance over time. Whatever happened to the Fairness Doctrine in America, emerging democracies like Nigeria need such regulation to build and stabilise that preferred system of government to be able to get to where the USA and UK have reached in governance.

Democracy, even in its fledging stage as obtained in Nigeria, should offer a participatory form of governance in which all the constituent-groups in a given society enjoy the rights to self-determination, equal representation at all levels of government, right to expression of views, equal opportunity to socioeconomic and political advancement as well as equal right and access to leadership position at all levels.

Akpan notes that:

In a free and democratic society, the press as a whole is the market place of political thoughts. The broadcast media exist to serve the information needs of the citizenry. Editors, commentators, anchormen and newsmen as a whole work on the principle that the public is entitled to all the facts in political situation and that on the basis of those facts; it can make its own decisions. ${ }^{20}$

Democracy presupposes that popular or mass participation by the citizenry in public affairs and access to public institutions is necessary for the sustenance

\footnotetext{
${ }^{19}$ Dominick (1990) at 412.

${ }^{20}$ Akpan (1985) at 219.
} 
of democracy. Anam states that "democracy and free media are symbiotic", He explains that democracy promotes freedom of expression, but free media further develop nascent democracies. Thus, while some democratisation was necessary to liberate the media, over time the media have become stronger, more vibrant and more of a voice for the people; promoting a more transparent democracy and a government that makes informed choices.

Stigliz emphasises that:

Essentially, meaningful participation in democratic processes requires informed participants. Secrecy reduces the information available to the citizenry, hobbling people's ability to participate meaningfully. ${ }^{22}$

On the other hand, openness is one of the most important checks on the abuse of public fiduciary responsibilities. While such openness may not guarantee that wise decisions will always be made, it would be a major step forward in the on-going evolution of democratic processes, a true empowerment of individuals to participate meaningfully in the decisions concerning the collective actions which have profound effects on their lives and livelihoods. Besley, Burgess and Prat emphasise that "a free or non-captured media can affect political outcomes through three routes namely: sorting, discipline and policy salience" 23 . Sorting refers to the process by which politicians are selected to hold office. The kind of information media provide can be important to voters who are deciding who to put in charge. This includes information about candidates' previous tract records. Their actions while in office may also be an important source of information about their underlying motivation or competence. By publishing stories that responsibly cast light on this, the media can be a powerful force.

The role of the media in achieving discipline in most relevant in situations of hidden action. This involves exposure of activities which perpetrators do not want the public to know. The media can also affect which issues are salient to voters.

Onuoha emphasises that:

a democratic media can be identified by its structure and functions. In terms of structure, it would be organised and controlled by ordinary citizens or their grassroots organisations. This could be one or a few individuals or bodies serving local or larger political, minority or other groups in the social and political arena. ${ }^{24}$

Herman asserts that media fitting these structural conditions would be bound to articulate demands of the general population because they are either part of it or instruments created to serve its needs. As regards functions, Herman ${ }^{25}$ explains

\footnotetext{
${ }^{21}$ Anam (2002) at 267.

${ }^{22}$ Stigliz (2002) at 30.

${ }^{23}$ Besley, Burgess and Prat (2002) at p. 49.

${ }^{24}$ Onuoha (1999) at 119.

${ }^{25}$ Herman (1994) at 40.
} 
that a democratic media will aim first and foremost at serving the informational, cultural and communication needs of the members of the public which the media institutions comprise or represent. Moreover, a democratic media would recognise and encourage diversity. It would allow and encourage minorities to express their views and build their own communities' solidarity within the large community. This would follow from the democratic idea of recognising and encouraging individual differences and letting all such flowers bloom irrespective of financial capacity and institutional power.

Sotunmbi suggests that:

To popularise and sustain democracy, radio and television organisations would have to air more than one point of view on controversial political issues, educate the audience on their political and constitutional rights, provide for an objective debate of policy issues, promote accountability in public office and expose boardroom intrigues and improper business deals. $^{26}$

The Nigerian Broadcasting Code $^{27}$ envisages that broadcasting shall contribute to the development of national unity and participatory democracy. Therefore, the Code stipulates that the political objectives of broadcasting in Nigerian shall be to:

i. create and promote political awareness among the people to achieve a democratic society;

ii. inculcate in the people the spirit of tolerance of all shades of opinions, and

iii. promote social justice based on the responsibilities and rights of the individual in the society.

In the opinion of $\mathrm{Oso}^{28}$ democracy will not take root in Nigeria unless the process and means of public communication is democratised. This means, the more diverse and richer the voices and ideas in the market place, the better for democracy in Nigeria.

Sotunmbi advises that the:

Broadcast media should promote the activities of pressure groups, especially professional associations, intellectuals, artistes and human right associations who tend to serve as the conscience of society. Indeed, the electronic media should promote freedom of expression and freedom of association and seek to enhance the protection of ordinary citizens and minority groups under the law. ${ }^{29}$

\footnotetext{
${ }^{26}$ Sotunmbi (1999) at 215.

${ }^{27}$ Nigerian Broadcasting Code , 2010 at 14-15.

${ }^{28}$ Oso (2003) at 18.

${ }^{29}$ Sotunmbi (1999) at 215.
} 
Sotunmbi canvasses that broadcasters should have the freedom to determine the philosophy, content and mode of execution of their programmes without external pressure or interference.

In the above respect, Traber has this to say:

Democratisation of communication and democratisation of society are of course interdependent. They are variables of the same reality. To democratise communication therefore means to democratise society, and vice versa. But from our perspective of public philosophy, it is precisely the role of the media to be a catalyst in the democratic process. ${ }^{30}$

Also, the Latin American media experts, reported by Traber, at a meeting in Embu, Brazil, in 1982 affirm that:

Democracy is above all a fundamental human attitude expressed in communication by abolishing authoritarian forms and relying on the conscious, organised and collective action of the oppressed. Pluralistic participation of social actors should manifest itself in the different levels of communication process, particularly in the production, distribution and assumption of cultural goods.

Traber suggests a change in the 'social actors' criterion of news selection. By this, he means that the masses, instead of the elites, should become the focus when considering the 'who' of an event. He posits that: alternative criteria of news need to be established, practised and taught, and they are to a large extent a reversal of the news values of conventional journalism. What is needed first and foremost are alternative social actors, or the re-definition of the criterion of prominence. ${ }^{31}$

According to him, social actors are those groups of persons or persons who almost as a matter of right; are covered by the media and can speak through them. The very process of publicity makes them prominent, even those who otherwise might be totally insignificant in terms of their public service. To bring about a new definition of social actors in the 'new journalism', Traber suggests that:

If the media make a conscious effort to report on, and in fact give preferential treatment to the manual labourers and their agricultural and industrial organisations, to the women and their groups, to the youths and children, and to the forgotten minorities, these persons and groups do become social actors who can speak to the public at large and thus occupy a place in the public consciousness. ${ }^{32}$

\footnotetext{
${ }^{30}$ Traber (1987) at 66.

${ }^{31}$ Traber (1987) at 73.

${ }^{32}$ Traber (1987) at 66.
} 
If Traber's suggestion is implemented, every citizen would become a potential news-maker, instead of the present situation whereby high social status serves as one of the major considerations to merit media coverage. This implies that mass media operators should be alive to their social responsibility. McQuail $^{33}$ highlights the main principles of social responsibility to include:

a. Media should accept and fulfil certain obligations to society.

b. These obligations are mainly to be met by setting high or professional standards of information, truth, accuracy, objectivity and balance.

c. In accepting and applying these obligations, media should be selfregulating within the framework of law and established institutions.

d. The media should avoid whatever might lead to crime, violence or civil disorder or give offence to minority groups.

e. The media as a whole should be pluralistic and reflect the diversity of their society, giving access to various points of view and right of reply.

f. Society and public, following the first named principle, have a right to expect high standards of performance and intervention can be justified to secure the, or a, public good.

g. Journalists and media professionals should be accountable to society as well as to employers and the market.

Social responsibility as a mass media principle acknowledges the existence of various ethnic, religious, political and cultural sensitivities of individuals and groups. Expanding and guaranteeing freedom of speech thus require consideration for the right of individuals to access in broadcasting, which in turn requires more diversity, a broader spectrum of opinions and points of view, and a reversal of current policies that restrict access to establishment spokespersons. Kellner ${ }^{34}$ posits that a democratic broadcasting philosophy would hold that broadcasting in a democratic society should help make possible an informed citizenry by airing controversial issues of public importance from a variety of positions. It should facilitate access to citizens and public interest groups and the public interest should be determined by the extent to which broadcasting promotes a robust democracy and helps produce a democratic public sphere.

\section{Conclusion}

Political reporting can be said to be the catalyst for democracy and good governance. It cannot be effective if it does not guarantee equal opportunity; fairness and engender democratisation of communication. Therefore, the political reporter must exhibit a high sense of social responsibility in the performance of his duties.

\footnotetext{
${ }^{33} \mathrm{McQuail}(1987)$ at 11.

${ }^{34} \operatorname{Kellner}(1990)$ at 185 ,
} 


\section{References}

Akpan, E. (1985).'Broadcast Journalism in a Multi-party State', in Onuora E. Nwuneli (ed.) Mass Communication in Nigeria: A Book of Reading. Enugu: Fourth Dimension Publishers.

Akpan, E. (1991). 'Ethos as a factor in Communication: Possible Implications for the Development of Mass Communication in Nigeria', in Solomon Unoh (ed.) Topical Issues in Communication Arts. Vol. 11, Uyo: Modern Business Press.

Anam, M. (2002). 'The Media and Development in Bangladesh', in James D. Wolfensohn (ed.). The Right to Tell: The Role of the Mass Media in Economic Development. Washington: World Bank Institute.

Besley, T., Robin, B. and P. Andrea (2002). 'Mass Media and Political Accountability', in James D. Wolfensohn (ed.) The Right to Tell: The Role of the Mass Media in Economic Development. Washington: World Bank Institute.

Chester, G., Garrison, G.R. and E.E, Willis (1971). Television and Radio. New York: Meredith Corporation.

Dominick, J. (1990). The Dynamics of Mass Communication. New York: McGraw-Hill.

Gurevitch, M. and J.G. Blumler (1977). 'Linages between the Mass Media and Politics: A Model for the Analysis of Political Communications Systems', in James Curran, Michael Gurevitch and Janet Woollacatt (eds.) Mass Communication and Society. London: Edward Arnold Publishers Ltd.

Hovland, C.I. and W. Walter (1961). 'The Influence of Source Credibility on Communication Effectiveness', in Wilbur Schramm (ed.) The Process and Effects of Mass Communication. Urbana: University of Illinois Press, 275 - 288.

Islam, R. (2002). 'Into the Looking Glass: What the Media Tell and Why - An Overview', in Joseph D. Wolfensohn (ed.) The Right to Tell: The Role of the Mass Media in Economic Development. Washington: World Bank Institute.

Kellner, D. (1990). Television and the Crisis of Democracy. Boulder, Colorado: Westview Press.

Lasode, O. (1994). Television Broadcasting: The Nigerian Experience (1959 - 1992). Ibadan: Caltop Publications (Nigeria) Limited.

Mackay, I. K. (1964). 'Recent Political Theory on Mass Communication Potential in Political Campaigns', in Everette Dennis, Donald Gillmore and Arnold Ismack (eds.) Enduring Issues in Mass Communication. St. Paul Minnesota: West Publishing Company.

McQuail, D. (1987). Mass Communication Theory. London: Sage Publications.

Nwodu, L. (2003). 'Mass Media and Management of Political Change', in Ikechukwu Nwosu (ed.) Polimedia: Media and Politics in Nigeria. Enugu: Prime Targets Ltd.

Nwuneli, O. (1985). 'Broadcast Regulation and Politicians of the first Republic', in Onuora Nwuneli (ed.) Mass Communications in Nigeria: A Book of Reading. Enugu: Fourth Dimension Publishers.

Onuoha, B. (1999). 'Media Pluralism and Democratic Culture in an Emerging Civil Society', in Luke Uche (ed.) Mass Communication, Democracy and Civil Society in Africa. Lagos: Smagh and Company Nigeria Limited.

Oso, L. (2003). 'Mass Media and Democracy: Enlarging the Space', in Ikechukwu Nwosu (ed.) Polimedia: Media and Politics in Nigeria. Enugu: Prime Targets Ltd.

Pate, U. (2003). 'Media Ethics in Political Reporting on the Broadcast Media in Nigeria', in Ikechukwu Nwosu (ed.) Polimedia: Media and Politics in Nigeria. Enugu: Prime Targets Ltd. 
Vol. 5, No. 3 Obot: Political Reporting: Its Regulatory Framework and Imperatives...

Sotunmbi, A. (1999). 'The Electronic Media and Sustainable Democracy in Nigeria', in Luke Uka Uche (ed.) Mass Communication, Democracy and Civil Society in Africa. Lagos: Smagh \& Company Nigeria Limited.

Stigliz, J. (2002). 'Transparency in Government', in Joseph D. Wolfensohn (ed.) The Right to Tell: The Role of the Mass Media in Economic Development. Washington: World Bank Institute.

Traber, M. (1987). 'Towards the Democratization of Public Communication: A Critique of the Current Criteria of News', in Africa Media Review 2(1):66-75.

Wilson, D. (2003). 'The Mass Media and Participatory Democratic Process: Mobilizing Nigerians for Elections', in Nigerian Journal of Mass Communication 2(1 \& 2):121.

Wilson, S. (1993). Mass Media and Mass Culture: An Introduction. New York: McGrawHill Inc.

Wolfensohn, J.D. (2002). Foreword in J. D. Wolfensohn (ed.). The Right to Tell: The Role of the Mass Media in Economic Development. Washington: World Bank Institute. 